\title{
EXEMPLO DE APLICAÇÃO DO SISTEMA GEOGRÁFICO DE INFORMAÇÃO ARC - INFO EM GEOLOGIA: SERRA DE CUBATÃO, SP
}

G.R.Sadowski

O Sistema Geográfico de Informação ARC/INFO é um software de base vetorial próprio para cartografia digital, que se divide em dois sub sistemas: cartográfico e banco de dados. 0 primeiro constitui-se no aplicativo ARC, que permite desenhar e designar, através de um sistema de coordenadas predefinido, curvas (arcos), áreas (polígonos) e pontos (nós). Além de permitir editoração interativa através do programa EDIT, possui um sistema de conversão de coordenadas e projeções cartográficas, bem como aplicativos que permitem desenhar secções topográficas e blocos diagramas em 3D com simulações de relevo. O banco de dados (INFO) permite atribuir e relacionar os atributos, seja com parâmetros quantitativos, seja por lógica booleana. Destarte, podemos atribuir cores a diferentes polígonos ou então características outras como composição petrográfica, química ou qualquer outro parâmetro de interesse e relacioná-los. Por exemplo, introduzidos dados de composição geoquímica de maciços intrusivos, podemos solicitar que sejam desenhados somente aqueles cujos teores de $\mathrm{SiO}_{2}$ estejam em um certo intervalo. Ou então traçar aquelas áreas constituídas por granitos e onde o teor em um elemento qualquer somado a outro seja de interesse prospectivo.

No caso da Serra de Cubatão, construímos uma base cartográfica indexando as diferentes curvas de nível para construir o modelo digital topográfico. A seguir, em outra planilha desenhamos a Geologia. Feito isto, passa-se à fase de manipulação gráfica. Obtivemos o bloco diagrama do terreno visto do Sul para Norte sob uma perspectiva de $x$ graus acima da linha do horizonte. Instruímos que o programa trace os contatos geológicos por cima do bloco diagrama, o que

é feito automaticamente. Paralelamente, podemos desenhar um mapa geológico colorido que dê a sensação de relevo através de sombreado superimposto. Interessados na relação estabilidade de encostas em função da litologia, podemos instruir o desenho de um mapa de declividades utilizando o programa de triangulação TIN. No caso, houve dificuldades devido ao padrão topográfico extremamente contrastante entre o planalto e a encosta da Serra, problema aparentemente sanado nas versões superiores existentes no mercado (utilizamos a versão 4.0). Todavia, conseguiu-se um resultado razoável. A impressão foi executada por um plotter eletrostático colorido no Laboratório de GIS do USGS em Denver, EUA.

Departamento de Geologia Geral, Instituto de Geociências, USP. 